\title{
EKSPLORASI DAN PERANCANGAN PROTOTIPE APLIKASI KANTOR MAYA UNTUK MENINGKATKAN SUSTAINABLE COMPETITIVE ADVANTAGE DI PERGURUAN TINGGI
}

\author{
Yusepaldo Pasharibu \\ Fakultas Ekonomika dan Bisnis, Universitas Kristen Satya Wacana \\ yusepaldo.pasharibu@staff.uksw.edu \\ Hari Sunarto \\ Fakultas Ekonomika dan Bisnis, Universitas Kristen Satya Wacana \\ hari.sunarto@staff.uksw.edu \\ Agus Sugiarto \\ Fakultas Ekonomika dan Bisnis, Universitas Kristen Satya Wacana \\ agus.sugiarto@staff.uksw.edu \\ Yunita Budi Rahayu Silintowe \\ Fakultas Ekonomika dan Bisnis, Universitas Kristen Satya Wacana \\ yunita.silintowe@staff.uksw.edu
}

\begin{abstract}
Sustainable competitive advantage for universities could not be separated from the information technology. Actually, some universities have been implemented this information technology, especially virtual office applications. Eventhough, the virtual office applications were implemented, but preliminary research found that those applications used were Online Transaction Processing only, not Online Analytical Processing that can be used to make decision. Based on those explanations, this research had been done to explore and design the virtual office prototype application for universities. Three methods were used to conduct this reseach, which were explorative, validation, and application design. Finally, prototype applications of virtual office dashboard, lecturer dashboard and accreditation dashboard to improve sustainable competitive advantage for universities were presented as this study result.
\end{abstract}

Keywords: virtual office, online analytical processing, university's sustainable competitive advantage

\section{PENDAHULUAN}

Keunggulan bersaing yang berkesinambungan (sustainable competitive advantage) tidak dapat dilepaskan dari peran teknologi informasi (Piccoli dan Ives, 
2005), demikian pula untuk perguruan tinggi. Salah satu aktifitas yang dilakukan oleh perguruan tinggi adalah aktifitas pengelolaan administrasi atau manajemen sistem informasi. Keberadaan teknologi informasi khususnya aplikasi teknologi informasi untuk administrasi tersebut akan meningkatkan efektifitas (Min-Seok et al., 2014) dan efisiensi dalam kinerja staff administrasi. Meningkatnya kinerja dari sumber daya manusia (staff) dalam mengelola informasi yang ada, akan menciptakan keunggulan bersaing (Kazlauskaitè dan Bučiūnienė 2008) bagi perguruan tinggi yang bersangkutan. Selain hal tersebut, dengan adanya aplikasi virtual, maka unit-unit dalam suatu organisasi (dalam hal ini adalah perguruan tinggi) yang saling berkaitan dapat terhubung dan saling mendukung, sehingga akan meningkatkan kinerja organisasi (Applebaum dan Blatt 1994; Kalleberg dan Moody 1994).

Namun, berdasarkan penelitian pendahuluan yang dilakukan (Pasharibu et al., 2013), pemanfaatan teknologi informasi di beberapa lingkungan perguruan tinggi masih sebatas Online Transaction Processing (OLTP), dimana sistem informasi kantor maya hanya bersifat pencatatan transaksi kegiatan atau aktivitas saja dan belum mencapai Online Analytical Processing (OLAP) yang mendukung fungsi pengambilan keputusan. Berdasarkan hal tersebut, penelitian ini dilakukan untuk menggali/menjajaki pengembangan sistem virtual office application di perguruan tinggi. Dari hasil penjajakan mengenai pengembangan sistem aplikasi virtual office tersebut, kemudian dirancang suatu prototipe untuk aplikasi dashboard administrasi dan dashboard dosen.

\section{TELAAH PUSTAKA}

\section{Sustainable Competitive Advantage}

Keunggulan bersaing yang berkesinambungan diidentifikasi sebagai keunggulan dalam mencipta strategi berbasis sumber daya dan penciptaan strategi dari respon pembelajaran cepat, yang didukung dengan pertimbangan serta gagasan dalam mengimplementasi strategi secara tangkas (Liu 2013). Konsep mendasar dari keunggulan bersaing adalah adanya penciptaan nilai dan distribusi, yang salah satunya diinisiasi dengan keberadaan teknologi informasi untuk mendukung keberlanjutan keunggulan bersaing tersebut (Piccoli dan Ives 2005).

\section{Aplikasi Teknologi Informasi}

Aplikasi teknologi informasi yang mendukung keunggulan bersaing merupakan salah satu sumber daya utama untuk mengelola sumber daya informasi dalam sebuah organisasi. Perkembangan teknologi informasi semakin nyata membuat berbagai kegiatan manusia semakin dimudahkan. Demikian juga dengan efisiensi kegiatan pelayanan kantor atau administratif yang tercipta dengan adanya aplikasi teknologi informasi (Min-Seok et al., 2014). Hal tersebut mendasari adanya peralihan dari berbagai pelayanan dan kegiatan perkantoran yang semula dilakukan 
secara konvensional menjadi kegiatan yang dilakukan secara virtual dengan dukungan aplikasi teknologi informasi. Adopsi sistem virtual akan membuat user dapat mengakses data relevan dengan tepat, lengkap dan konsisten yang memampukan pengambilan keputusan akan lebih cepat (Preis dan Seitz 2012). Kantor maya (virtual office) sendiri dapat didefinisikan sebagai otomatisasi kantor, meliputi manajemen kegiatan administratif dengan dukungan sistem komunikasi elektronik yang juga memungkinkan untuk melakukan aktifitas tersebut di tempat fisik yang berbeda (McLeod dan Schell 2007).

\section{Entreprise Resource Planning (ERP)}

Dalam perkembangan sistem informasi, saat ini konsep ERP sedang berkembang, dan banyak organisasi memanfaatkannya dalam proses bisnis. ERP dapat didefinisikan sebagai integrasi dari pengelolaan praktik bisnis dengan aplikasi teknologi. Dengan kata lain, sistem ERP merupakan sistem berbasis komputer yang memampukan pihak manajemen dapat mengelola sumber daya yang dimilikinya (McLeod dan Schell 2007). ERP pada awalnya banyak diterapkan pada organisasi manufaktur, namun juga sangat dimungkinkan untuk diadopsi dan diterapkan untuk organisasi lainnya. Salah satu kunci sukses dari pengimplementasian sistem ERP adalah pengelolaan atau sistem manajemen yang baik (Chaabouni dan Triki 2014), sehingga sangat tepat apabila organisasi yang dijadikan target integrasi ERP adalah lembaga pendidikan, khususnya perguruan tinggi yang diyakini memiliki pengetahuan yang memadai dalam manajemen. Data operasional dari ERP tersebut diintegrasikan ke dalam bentuk yang konsisten, terpercaya dan mudah tersedia untuk pelaporan, dengan memanfaatkan data warehouse. Data warehouse merupakan database dengan perangkat pelaporan dan query, yang menyimpan data saat ini dan data historis mengenai hal-hal potensial bagi pihak manajemen, serta menggabungkannya dalam pelaporan analisis manajemen (Loudon 2004). Pengaksesan informasi melalui data warehouse merupakan teknik yang tepat dalam mendukung kesuksesan user (Chenoweth et al., 2006), khususnya untuk memeroleh informasi secara tepat (real time), sehingga membuat user dapat menanggapi perubahan bisnis yang ada dengan cepat (Farooq 2013).

\section{METODA PENELITIAN DAN PERANCANGAN}

Terdapat tiga metoda yang digunakan dalam penelitian dan perancangan prototipe aplikasi virtual office untuk perguruan tinggi ini. Metoda pertama adalah eksplorasi, peneliti melakukan eksplorasi pada salah satu perguruan tinggi swasta yang ada di Indonesia. Eksplorasi yang dilakukan tersebut memiliki tujuan utama untuk mengidentifikasi kebutuhan aplikasi virtual office yang dibutuhkan oleh perguruan tinggi. Perguruan tinggi yang dipilih untuk dieksplorasi adalah UKSW (Universitas Kristen Satya Wacana) sebagai salah satu perguruan tinggi di Indonesia 
yang dinominasikan oleh ICT's Smartest Campus sebagai universitas terbaik di Jawa Tengah yang mengimplementasikan teknologi informasi dan komunikasi (Liu 2013).

Langkah selanjutnya yang dilakukan adalah validasi ke beberapa perguruan tinggi yang ada di Indonesia dengan metode in-depth interview. Validasi ini bertujuan untuk memberikan konfirmasi usulan model prototipe aplikasi virtual office yang dari hasil pembelajaran sistem informasi yang diimplementasikan di UKSW, dengan sistem informasi di beberapa perguruan tinggi yang ada di Indonesia. In-depth interview dilakukan di empat perguruan tinggi negeri maupun swasta yang ada di kota Semarang (2 perguruan tinggi), Jakarta (1 perguruan tinggi), dan Yogyakarta (1 perguruan tinggi), khususnya antara lain terdiri dari Wakil Rektor, programmer, kepala dan staff dari Unit Sistem Informasi dan Komunikasi.

Metode selanjutnya setelah dilakukan eskplorasi dan validasi adalah metode perancangan prototipe aplikasi virtual office untuk perguruan tinggi. Perancangan prototipe sistem aplikasi kantor maya diawali dengan usulan model dan identifikasi aliran data dalam sebuah data flow diagram (DFD). Selanjutnya, prototipe sistem kantor maya dibangun dan dikembangkan dengan menggunakan aplikasi Microsoft.Net, Visual Studio 2010, Dev Express 13.2.9, serta dukungan aplikasi database Microsoft SQL Server Express 2005.

\section{HASIL DAN PEMBAHASAN}

\section{Eksplorasi}

Pertama-tama, untuk mengidentifikasi aplikasi yang dibutuhkan oleh perguruan tinggi, dilakukan eksplorasi pada Departemen Teknologi dan Sistem Informasi di UKSW, yang disebut dengan BTSI (Biro Teknologi dan Sistem Informasi) dengan menggunakan semi-structured interview. Selain dengan BTSI, semi-structured interview juga dilakukan dengan salah satu dekan fakultas, beberapa dosen serta beberapa staf administrasi fakultas. Hasil eksplorasi dengan semistructured interview tersebut menunjukan bahwa kebutuhan pemakai (user) lebih ditekankan pada pengembangan model layanan sistem perkantoran maya (virtual office) yang mendukung kegiatan administrasi akademik dosen (dalam bentuk dashboard untuk dosen), administrasi perkantoran terutama sistem yang mendukung penerbitan surat-surat keputusan (SK), serta sistem yang mendukung kegiatan akreditasi program studi, terutama penyusunan dokumen borang akreditasi BAN-PT. Berdasarkan eksplorasi yang dilakukan juga diketahui bahwa beberapa aplikasi yang dibutuhkan tersebut sudah diimplementasikan di UKSW, namun aplikasi basis data yang ada masih terpisah-pisah, belum berbasis ERP (Enterprise Resource Planning) yang mengakomodasi data warehouse. Dengan kata lain, basis data dari tiap aplikasi yang ada tersebut belum terintegrasi secara optimal. Selanjutnya, berdasarkan hasil eksplorasi tersebut, diusulkan suatu model prototipe aplikasi virtual office, khususnya yang mengacu pada tiga dashboard utama (Gambar 1). 
Dashboard yang pertama adalah dashboard Administrasi Perkantoran yang berisi berbagai aktivitas administrasi, khususnya yang berkaitan dalam pembuatan surat keputusan di perguruan tinggi, seperti antara lain adalah SK Mengajar, SK Pengangkatan Wali Studi Mahasiswa, SK Pengangkatan Panitia Ujian, SK Penelitian, SK Pengabdian Masyarakat, SK Pengangkatan Gugus Tugas, dan SK Bimbingan Tugas Akhir. Dashboard yang kedua adalah dashboard dosen yang tuntutannya semakin meningkat atau tidak lagi hanya sebatas memenuhi Tri Dharma Perguruan Tinggi saja, namun terkadang juga perlu melakukan tugas manajerial atau tugas administratif lainnya. Oleh karena hal tersebut, maka draft dashboard dasar yang perlu dimiliki seorang dosen, antara lain terdiri dari Tri Dharma, Renumeration, JAFA (Jabatan Fungsional Akademik), BKD (Beban Kinerja Dosen), Library and Data Sources serta Tugas Manajerial. Selanjutnya, dashboard yang ketiga adalah dashboard borang akreditasi yang bertujuan untuk menentukan kelayakan program dan satuan pendidikan pada jalur pendidikan formal dan non-formal setiap jenjang dan jenis pendidikan. Di Indonesia, akreditasi program studi dan perguruan tinggi di lakukan oleh BAN-PT (Badan Akreditasi Nasional Perguruan Tinggi) yang dibentuk oleh Menteri Pendidikan dan Kebudayaan pada tahun 1994. BAN-PT sendiri merupakan lembaga yang memiliki kewenangan untuk mengevaluasi dan menilai, serta menetapkan status dan peringkat mutu program studi berdasarkan standar mutu yang telah ditetapkan (BAN-PT 2009).

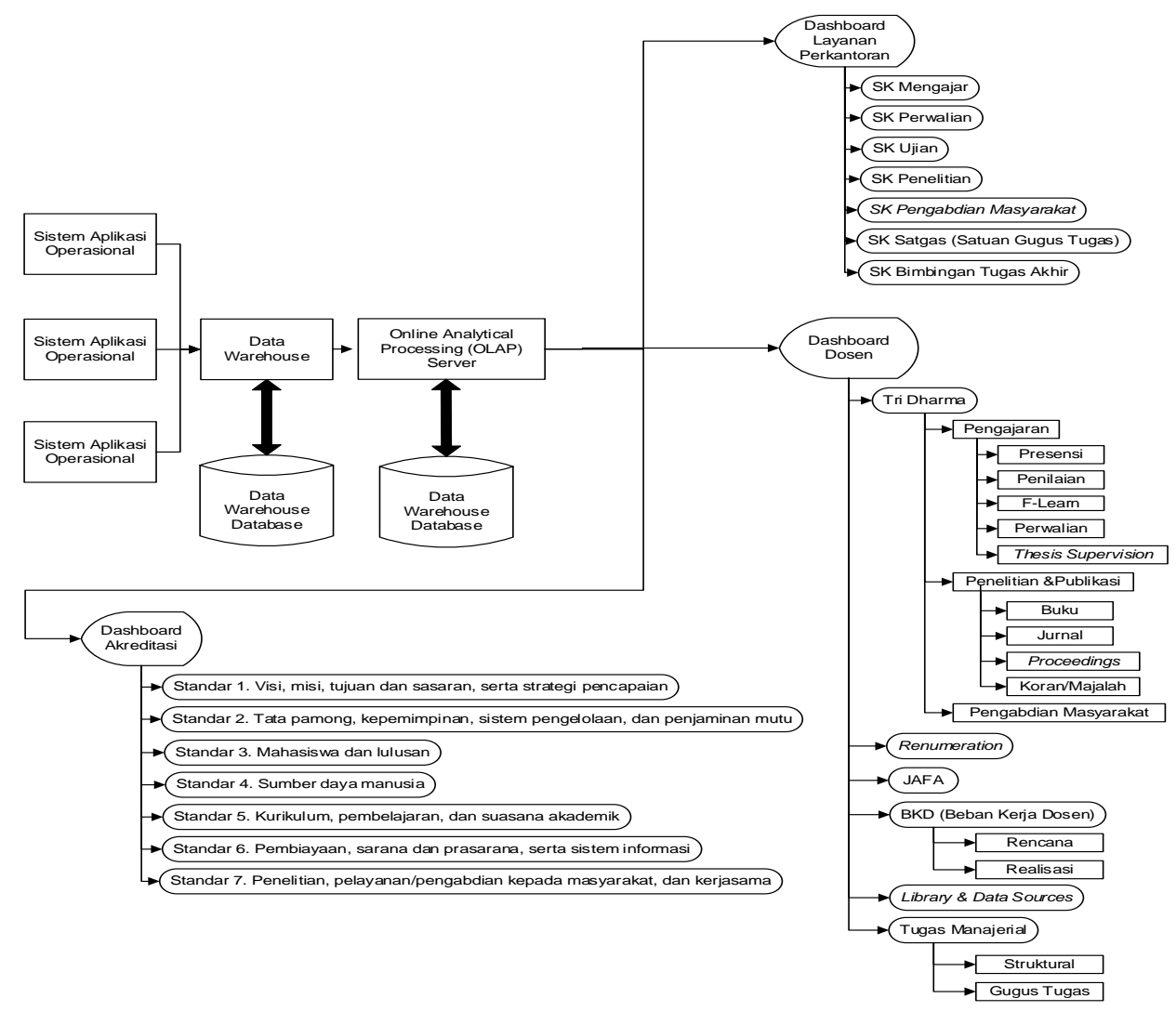

Gambar 1

Usulan Model Prototipe Aplikasi Virtual Office 


\section{Validasi dengan Beberapa Perguruan Tinggi di Indonesia}

Metoda kedua yang dilakukan setelah diperoleh pemahaman mengenai kebutuhan aplikasi virtual office adalah proses validasi dengan menggunakan indepth interview ke beberapa perguruan tinggi yang ada di Indonesia. Pokok bahasan utama dari validasi merupakan hal yang berkaitan dengan pengembangan dan implementasi virtual office, khususnya adalah apakah universitas-universitas tersebut telah menerapkan ERP (enterprise resource planning) dalam mengembangkan sistem informasi di masing masing universitas. Dengan kata lain, fokus validasi adalah seberapa jauh universitas pembanding melaksanakan IT Blue print masing masing. Secara umum, semua universitas mengelompokkan kebutuhan informasi kedalam sub-sistem yang hampir sama, namun dengan nama yang berbeda. Sub-sistem informasi yang dimaksud adalah: (1) administrasi akademik, (2) ELearning, (3) Library Management (4) Research and Publication, (5) Budgeting, Finance and Accounting, (6) Human Resource Management (7) Fixed Asset and Room Management serta (8) Office (Administrative) Management. Disamping itu, kebutuhan multimedia untuk keperluan komunikasi dan pembelajaran juga menjadi bagian sistem.

Disisi lain, proses pengembangan sistem informasi universitas terdapat dua kutub yaitu (a) sentralisasi yaitu dari pusat ke unit, dimana universitas memiliki unit layanan informasi dan (b) pola desentralisasi yaitu pengembangan mulai dari unit ke universitas, dimana masing masing unit, fakultas, mengembangkan sendiri sendiri kemudian pusat melakukan integrasi. Namun demikian, pada prinsipnya ditemukan kesamaan dimana ke empat universitas melakukan pengembangan software masing masing secara internal. Meskipun ada keberagaman pengembangan di fakultas, namun ada kecenderungan terjadinya konvergensi dan kebutuhan integrasi melalui standardisasi prosedur dan struktur data. Integrasi tersebut perlu dilakukan oleh karena adanya berbagai keperluan, seperti keperluan akreditasi, kebutuhan peningkatan layanan, serta kebutuhan informasi top eksekutif (Rektor dan Wakil Rektor). Lebih lanjut lagi, dari hasil in-depth-interview diketahui pula bahwa arah pengembangan sistem informasi yang dilakukan mengarah pada sistem informasi manajemen berbasis ERP. Secara alamiah, universitas yang menjadi pembanding dalam validasi ini memiliki tantangan yang sama, khususnya dalam upaya pemenuhan kebutuhan informasinya. Berdasarkan paparan tersebut, maka dapat disimpulkan bahwa metoda kedua ini memperkuat model prototipe aplikasi virtual office yang diusulkan peneliti.

\section{Perancangan Prototipe Aplikasi Virtual Office untuk Perguruan Tinggi}

Berdasarkan kedua metoda yang telah dilakukan atau setelah diperoleh pemahaman dan konfirmasi yang lebih mendalam mengenai kebutuhan akan sistem yang dikembangkan, selanjutnya dilakukan perancangan prototipe aplikasi, khususnya untuk aplikasi layanan perkantoran dan dosen. Sedangkan untuk aplikasi 
akreditasi, perancangan prototipe dashboard akreditasi tersebut didesain mengikuti format aplikasi yang dikeluarkan oleh BAN-PT.

\section{Dashboard Perkantoran}

Prototipe aplikasi perkantoran merupakan prototipe yang dibangun dan dikembangkan untuk pembuatan beberapa surat keputusan (SK) oleh pimpinan perguruan tinggi secara otomatis. Berikut adalah dashboard layanan perkantoran, khususnya yang berupa aktifitas administrasi pembuatan surat keputusan di perguruan tinggi. Perancangan prototipe sistem aplikasi kantor maya dilakukan melalui identifikasi aliran data dalam sebuah Data Flow Diagram (DFD). DFD sendiri dapat diidentifikasikan sebagai grafik aliran data dalam suatu organisasi yang meliputi sumber dan tujuan data, aliran data, proses transformasi serta penyimpanan data (Romney dan Steinhart 2015)

Perancangan DFD yang pertama adalah untuk dashboard layanan perkantoran (Gambar 2). Sistem dashboard administrasi perkantoran membutuhkan beberapa data pendukung dari fakultas yang diperlukan dalam usulan pembuatan beberapa Surat Keputusan (SK), seperti SK mengajar, penelitian, satuan gugus tugas, dan wali studi. Usulan surat keputusan tersebut, kemudian akan diotorisasi oleh pihak rektorat. Selanjutnya, berkaitan dengan data mengajar yang diusulkan untuk menjadi SK mengajar, oleh sistem data ini akan diolah menjadi jadwal kuliah yang kemudian diproses lebih lanjut oleh Manajemen Ruang demi keperluan pengaturan kelas yang dapat digunakan untuk proses belajar-mengajar tersebut.

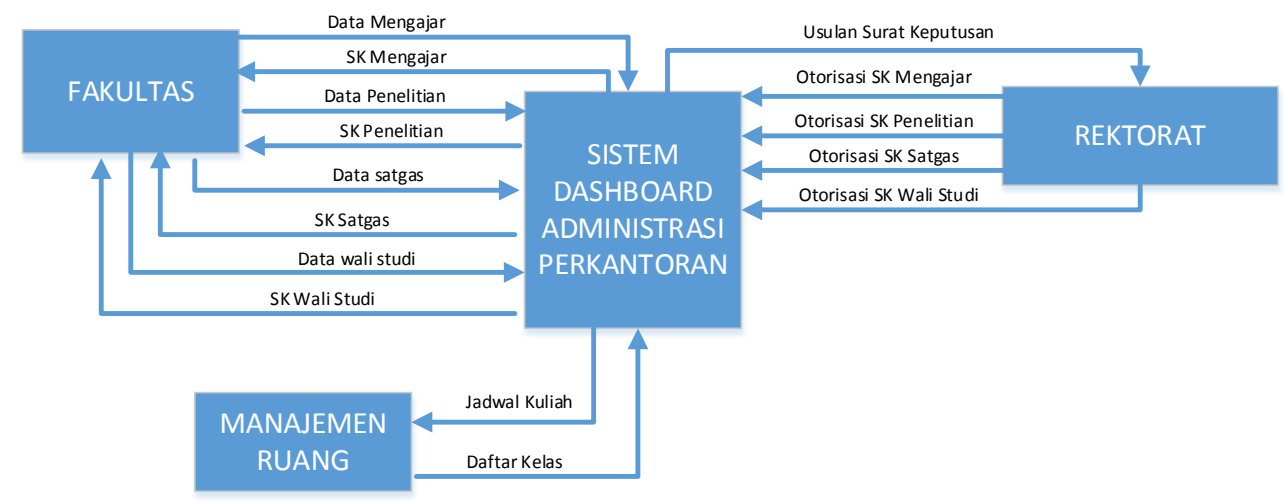

Gambar 2

DFD Prototipe Perkantoran

Berdasarkan DFD tersebut, terdapat beberapa data yang diperlukan dalam perancangan aplikasi sistem dashboard administrasi perkantoran. Untuk SK Mengajar, data yang dibutuhkan antara lain adalah nama dosen, nama matakuliah, keterangan (mandiri, team teaching, mandiri paralel), jumlah SKS (satuan kredit semester) dan jumlah mahasiswa. Selanjutnya juga dibutuhkan informasi mengenai data pendukung untuk konsideran dan diktum, yaitu menimbang, mengingat, memperhatikan dan menetapkan (aplikasi yang dirancang menyediakan template 
untuk informasi data pendukung ini). Output yang dihasilkan dari sistem penjadwalan ini berupa daftar kelas, yang dijadikan sebagai dasar pembuatan jadwal dosen. Output jadwal perkuliahan kemudian diproses bersama-sama dengan template SK Mengajar. Selanjutnya, hasil proses berupa usulan SK Mengajar akan diteruskan sistem untuk di otorisasi oleh Rektor.

Berikut langkah-langkah yang diperlukan dalam pembuatan SK Mengajar. Pertama-tama user membuka, menambah atau mengedit template surat keputusan yang telah disediakan oleh sistem sesuai kebutuhan (Lampiran Gambar 6. Menu Surat Keputusan). Selanjutnya, user melakukan konfigurasi template surat keputusan. Pada konfigurasi ini, pengguna diminta untuk mengisi data dasar konsideran dan diktum dalam sebuah surat keputusan yang pada umumnya digunakan (Lampiran Gambar 7. Form Edit Template Konsideran dan Diktum Surat Keputusan).

Setelah itu, user memilih template dan mengisi form yang sesuai dengan SK yang dikehendaki, dalam hal ini adalah SK Mengajar (Lampiran Gambar 8. Form Edit Field Surat Keputusan). Selanjutnya data SK Mengajar tersebut akan masuk dalam menu surat keputusan yang dapat dilihat kembali dengan memproses menu Show in Report (Lampiran Gambar 9. Menu Surat Keputusan Mengajar). Tampilan dari SK Mengajar tersebut yang meliputi lampiran jadwal matakuliah yang diampu oleh masing-masing dosen pengampu mata kuliah yang bersangkutan adalah sebagai berikut (Lampiran Gambar 10. Tampilan Draf Surat Keputusan Mengajar beserta Lampiran).

Mengenai SK Satgas (Satuan Gugus Tugas), pertama-tama, data usulan nama, tujuan, masa kerja, rincian tugas dan penetapan personil satgas dari fakultas akan diinput ke dalam sistem, yang kemudian diteruskan ke pihak rektorat untuk keperluan otorisasi sekaligus referensi rektorat untuk pembentukan satgas. SK selanjutnya adalah pembuatan SK Penelitian, yang prosesnya dimulai dari dosen yang bersangkutan menginput rancangan penelitian pada Repository Riset fakultas. Berdasarkan repository yang ada, usulan penelitian tersebut diproses menjadi SK Penelitian yang akan diotorisasi oleh rektor dan menjadi acuan penelitian yang akan dilakukan oleh dosen. Proses yang terakhir adalah pembuatan SK Wali Studi yang dimulai dari fakultas menentukan jumlah mahasiswa yang akan menjadi anak walian dari masing-masing dosen. Selanjutnya, data tersebut diproses dengan template yang akan menghasilkan SK Wali Studi per semester yang kemudian diotorisasi oleh Dekan Fakultas.

Secara umum, proses pembuatan SK yang lain memiliki prosedur pembuatan yang tidak jauh berbeda dengan SK Mengajar. Berikut ini adalah tampilan dari beberapa SK yaitu SK Satgas (Lampiran Gambar 11. Surat Keputusan Satuan Gugus Tugas), SK Penelitian (Lampiran Gambar 12. Surat Keputusan Tugas Penelitian) dan 
SK Wali Studi (Lampiran Gambar 13. Surat Keputusan Pengangkatan Wali Studi Mahasiswa).

\section{Dashboard Administrasi Dosen}

Selanjutnya, perancangan DFD yang kedua adalah untuk aplikasi administrasi dosen (Gambar 11).

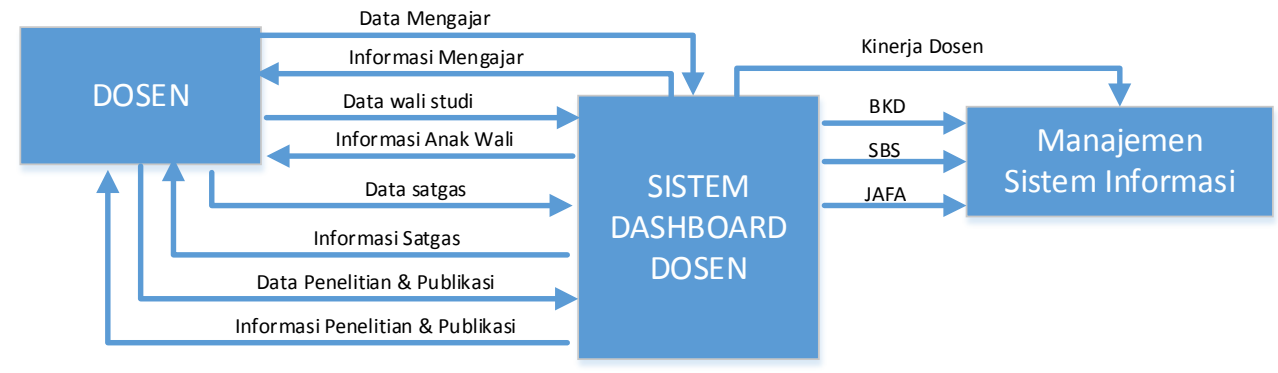

Gambar 3

DFD Prototipe Administrasi Dosen

Data pendukung prototipe administrasi dosen berasal dari basis data surat keputusan, data publikasi, data penelitian, data pengabdian masyarakat, data mengajar dan data satgas. Sedangkan hasil atau ouput dari prototipe ini adalah dokumen pengajuan kenaikan JAFA (Jabatan Fungsional Akademik), kenaikan golongan internal, dokumen laporan kinerja dosen dalam bentuk BKD (Beban Kinerja Dosen) dan laporan SBS (Satuan Beban Semester). Untuk mempermudah pimpinan atau pejabat struktural atau manajemen fakultas dalam mengambil keputusan, maka dashboard dosen ini dilengkapi pula dengan dashboard fakultas bagi pimpinan (Gambar 12).

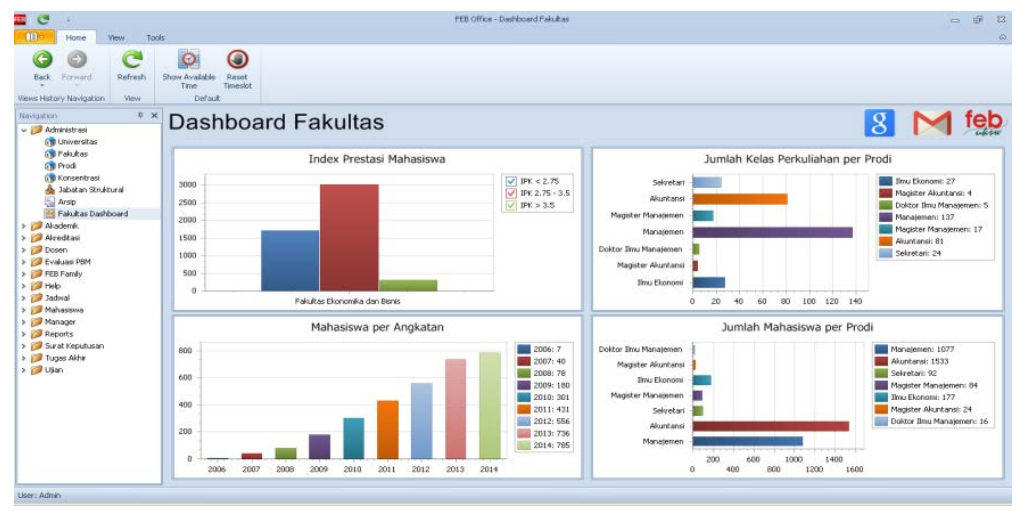

\section{Gambar 4 \\ Dashboard Fakultas}

Melalui dashboard ini, pimpinan dapat melihat informasi yang dibutuhkan dengan cepat, informasi tersebut antara lain seperti indeks prestasi mahasiswa, jumlah kelas perkuliahan tiap program studi, jumlah mahasiswa tiap angkatan, maupun jumlah mahasiswa tiap program studi dengan tampilan grafis. Selain bagi 
pimpinan, dashboard dosen juga dirancang untuk dapat membantu dosen yang bersangkutan melihat atau mengevaluasi kinerjanya, salah satunya dari ukuran tugas akademik atau lebih luas lagi dari sudut pandang Tri Darma Perguruan Tinggi yang wajib dilakukan oleh tiap-tiap dosen (Lampiran Gambar 13. Dashboard Dosen untuk Tugas Akademik).

Selain hal yang disebutkan sebelumnya, dashboard dosen pada dasarnya merupakan sistem yang digunakan untuk merekam, menyimpan dan mengintegrasikan data kinerja dosen, kemudian menghasikan beberapa dokumen kinerja dosen yang berupa Laporan Beban Kerja Dosen (BKD), Laporan Beban Satuan Semester (SBS) per dosen versi internal perguruan tinggi, dan dokumen pengusulan kenaikan Jabatan Fungsional Akademik (JAFA) serta kenaikan golongan kepangkatan internal. Atau dengan kata lain, prototipe administrasi dosen pada dasarnya adalah proses integrasi data dari berbagai data dalam database yang kemudian ditampilkan dalam beberapa format laporan. Beberapa tampilan selanjutnya dari dashboard dosen yang telah dirancang dapat dilihat pada Lampiran Gambar 14 hingga Gambar 20.

\section{Dashboard Akreditasi}

Data pendukung komponen akreditasi merupakan data-data yang telah disediakan oleh sistem berupa data mahasiswa, data dosen, data fasilitas, data admisi, data jadwal dan data kurikulum yang semuanya digunakan sebagai sumber data dalam proses penyusunan borang akreditasi dalam 7 standar. Jenis data terdiri dari data kualitatif dan data kuantitatif. Data kualitatif merupakan data yang berupa huruf, kata dan kalimat dalam bentuk deskripsi suatu objek tertentu yang tidak bisa dioperasikan secara matematis. Sedangkan data kuantitatif merupakan data berupa angka yang bisa dioperasikan secara matematis.

Prototipe aplikasi akreditasi menyesuaikan template akreditasi yang disediakan oleh sistem yang telah sesuai dengan 7 standar akreditasi dalam borang akreditasi Badan Akreditasi Nasional Perguruan Tinggi (BAN-PT). Template tersebut meliputi: Standar 1 Visi, Misi, Tujuan dan Sasaran, serta Strategi Pencapaian; Standar 2 Tata Pamong, Kepemimpinan, Sistem Pengelolaan, dan Penjaminan Mutu; Standar 3 Mahasiswa dan lulusan; Standar 4 Sumber Daya Manusia; Standar 5 Kurikulum, Pembelajaran dan Suasana Akademik; Standar 6 Pembiayaan, Sarana dan Prasarana, serta Sistem Informasi; Standar 7 Penelitian, Pelayanan/Pengabdian kepada Masyarakat, dan Kerjasama. Hasil yang dihasilkan oleh prototipe akreditasi adalah berupa dokumen borang akreditasi program studi, sesuai standar borang BAN-PT.

Perancangan prototipe untuk aplikasi akreditasi ini pada prinsipnya didesain mengikuti format aplikasi yang dikeluarkan oleh BAN-PT. Perancangan untuk aplikasi ini lebih difokuskan pada penyimpan data borang akreditasi dalam basis data yang dapat diakses kembali untuk re-akreditasi selanjutnya. Pertama-tama untuk 
mengawali penggunaan aplikasi, user membuka menu utama yang berisi tentang tujuh standar akreditasi sesuai BAN-PT (Gambar 21).

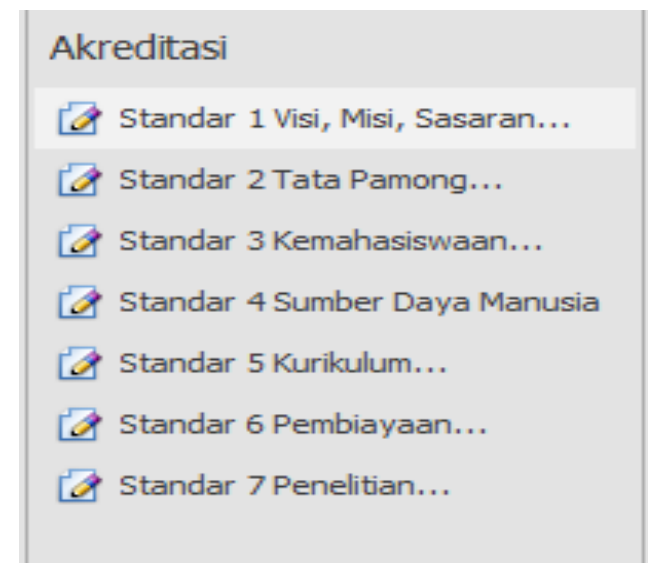

\section{Gambar 5 \\ Menu Utama Prototipe Akreditasi}

Selanjutnya, user menentukan dan melakukan pengisian atau perubahan pada template salah satu standar borang akreditasi yang telah tersedia di dalam sistem. Draft form dokumen yang telah diisi secara lengkap (Lampiran Gambar 22) akan disimpan dalam basis data.

\section{SIMPULAN}

Pengembangan model dan prototipe aplikasi pelayanan kantor maya di UKSW pada dasarnya sudah pada pembangunan sistem dan pemanfaatannya. Namun, hasil eksplorasi menunjukkan bahwa pengembangan aplikasi kantor maya dibangun tanpa konsep ERP dan integrasi data (data warehouse) belum terakomodasi. Integrasi data merupakan fokus dari pemodelan yang diusulkan. Validasi ke empat perguruan tinggi yang ada di Indonesia juga mendukung usulan model. Selanjutnya, dari model tersebut, dihasilkan perancangan prototipe untuk perguruan tinggi yang dimulai dengan desain Data Flow Diagram (DFD) sebagai dasar pembuatan prototipe aplikasi virtual office, khususnya dashboard administrasi, dosen dan akreditasi untuk perguruan tinggi.

Aplikasi prototipe yang dihasilkan dapat juga diaplikasikan untuk perguruan tinggi lain yang memiliki karakteristik dan kompleksitas kebutuhan transaksi layanan yang sama. Pemanfaatan sistem informasi melalui pelayanan kantor secara maya akan meningkatkan kualitas pelayanan kantor yang lebih baik kepada semua stakeholder yang selanjutnya akan memberikan keunggulan bersaing yang berkelanjutan, khususnya bagi perguruan tinggi yang bersangkutan. 
Penelitian dan perancangan prototipe aplikasi kantor maya ini tidak terlepas adanya keterbatasan yang dapat dijadikan peluang untuk agenda penelitian mendatang, antara lain adalah masih dibutuhkan penyempurnaan perancangan untuk dashboard akreditasi dan tampilan dari dashboard yang lainnya, sehingga aplikasi lebih user friendly.

\section{DAFTAR PUSTAKA}

BAN-PT. 2009. Buku III A Borang Akreditasi. Jakarta: BAN-PT.

Chaabouni, A., dan T. Abdelfattah. 2014. Usage d'un système ERP (Enterprise Resource Planning) au sein de deux PMI Tunisiennes: analyse basée sur la théorie de la gestion des connaissances. Revue Des Sciences De Gestion. Vol.49 No.266: 99-108.

Chenoweth, T., C. Karen, dan H. Demirkan. 2006. Seven key interventions for data warehouse success. Communications of the ACM. Vol.49 No.1 (January): 114-119.

Farooq, F. 2013. The data warehouse virtualization framework for operational business intelligence. Expert Systems. Vol.30 No.5 (November): 451-472.

Kazlauskaitè, R., dan I. Bučiūnienè. 2008. The role of human resources and their management in the establishment of sustainable competitive advantage. Engineering Economics. Vol.60 No.5: 78-84.

Liu, Y. 2013. Sustainable competitive advantage in turbulent business environments. International Journal of Production Research. Vol.51 No.10: 2821-2841.

Loudon, K. 2004. Management Information System, Managing The Digital Firm. Pearson Education.

McLeod, R., dan G. P. Schell. 2007. Management information systems. Upper Saddle River, N.J.: Pearson/Prentice Hall.

Min-Seok, P., A. Tafti, dan M. S. Krishnan. 2014. Information technology and administrative efficiency in us state government: A stochastic frontier approach. MIS Quarterly. Vol.38 No.4 (December): 1079-A16.

Pasharibu, Y., H. Sunarto, A. Sugiarto, dan Y. B. R. Silintowe. 2013. University management information system: Is that supportive enough and is it already integrated? Proceedings The 2nd International Conference on Information Systems for Business Competitiveness: 192-195.

Piccoli, G., dan B. Ives. 2005. IT-dependent strategic initiatives and sustained competitive advantage: A review and synthesis of the literature. MIS Quarterly. Vol.29 No.4 (December): 747-776. 
Preis, M., dan J. Seitz. 2012. Faster and better decisions in changing environments using a hybrid approach of data warehouse integration. Economics \& Management. Vol.17 No.2: 754-760.

Romney, M. B., dan P. J. Steinbart. 2015. Accounting Information System Thirteen Edition. Pearson.

TeSCA. 2013. Rangking TeSCa 2013. Available at http://tescaindonesia.org. 


\section{LAMPIRAN GAMBAR}

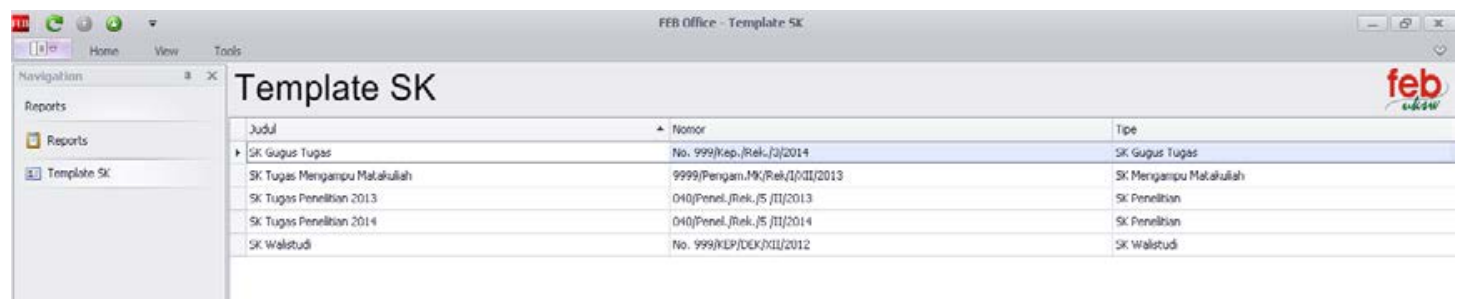

Gambar 6

Menu Surat Keputusan

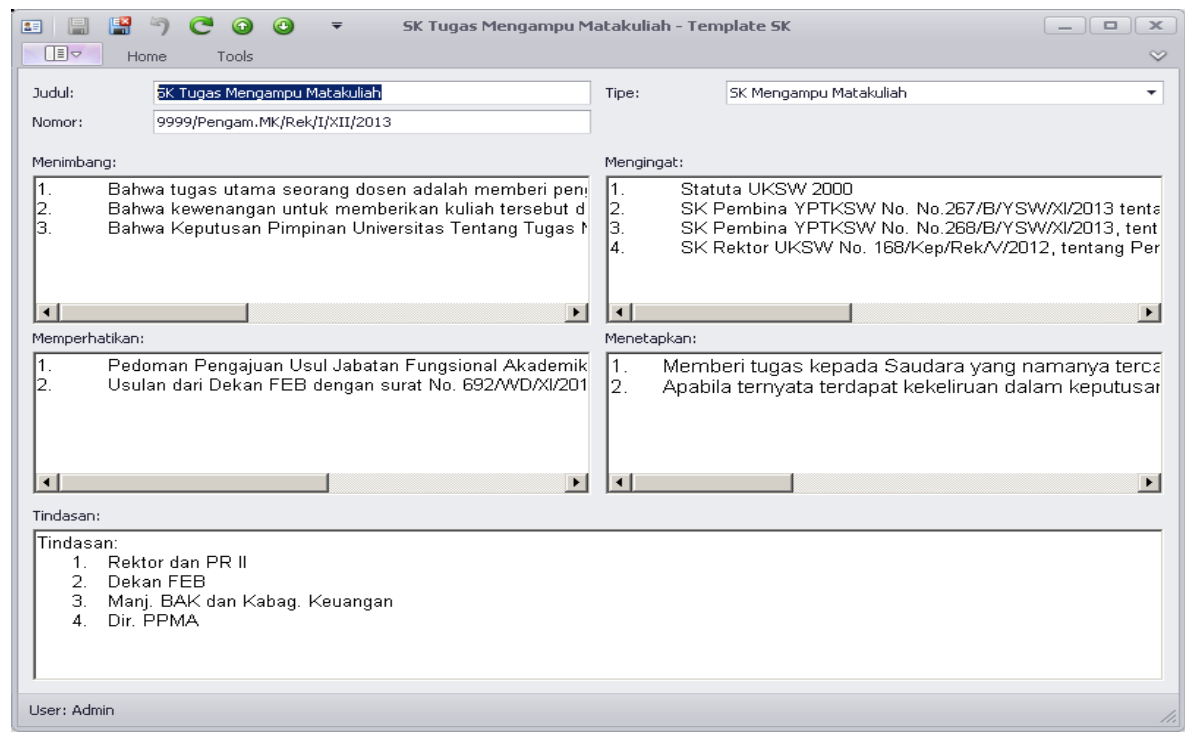

Gambar 7

Form Edit Template Konsideran dan Diktum Surat keputusan

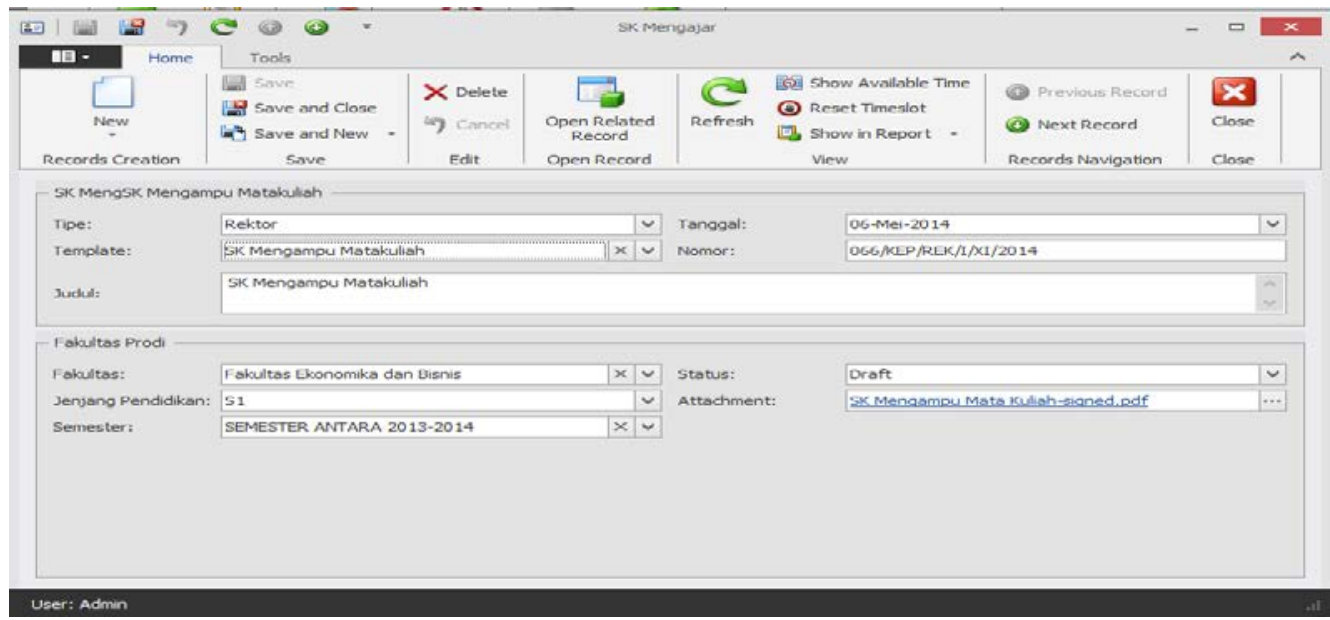

Gambar 8

Form Edit Field Surat Keputusan 


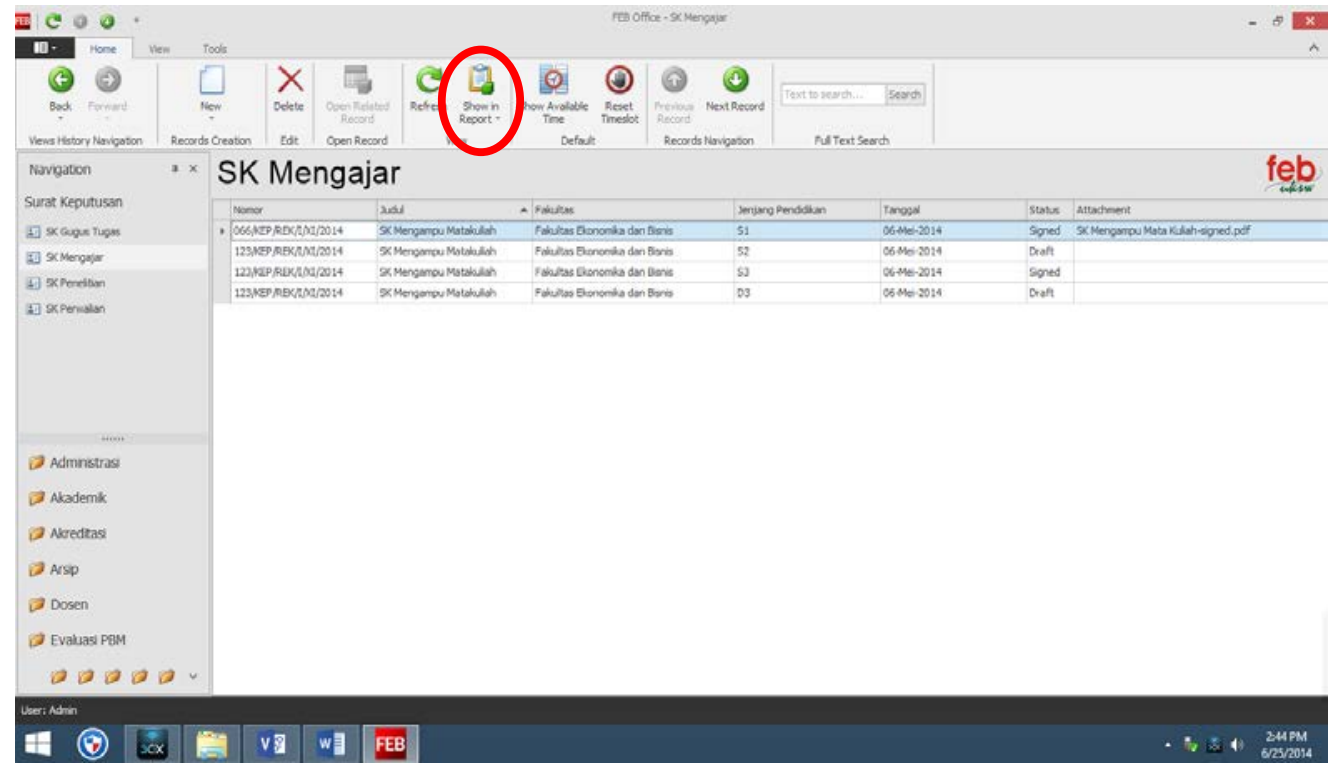

Gambar 9

Menu Surat Keputusan (SK) Mengajar

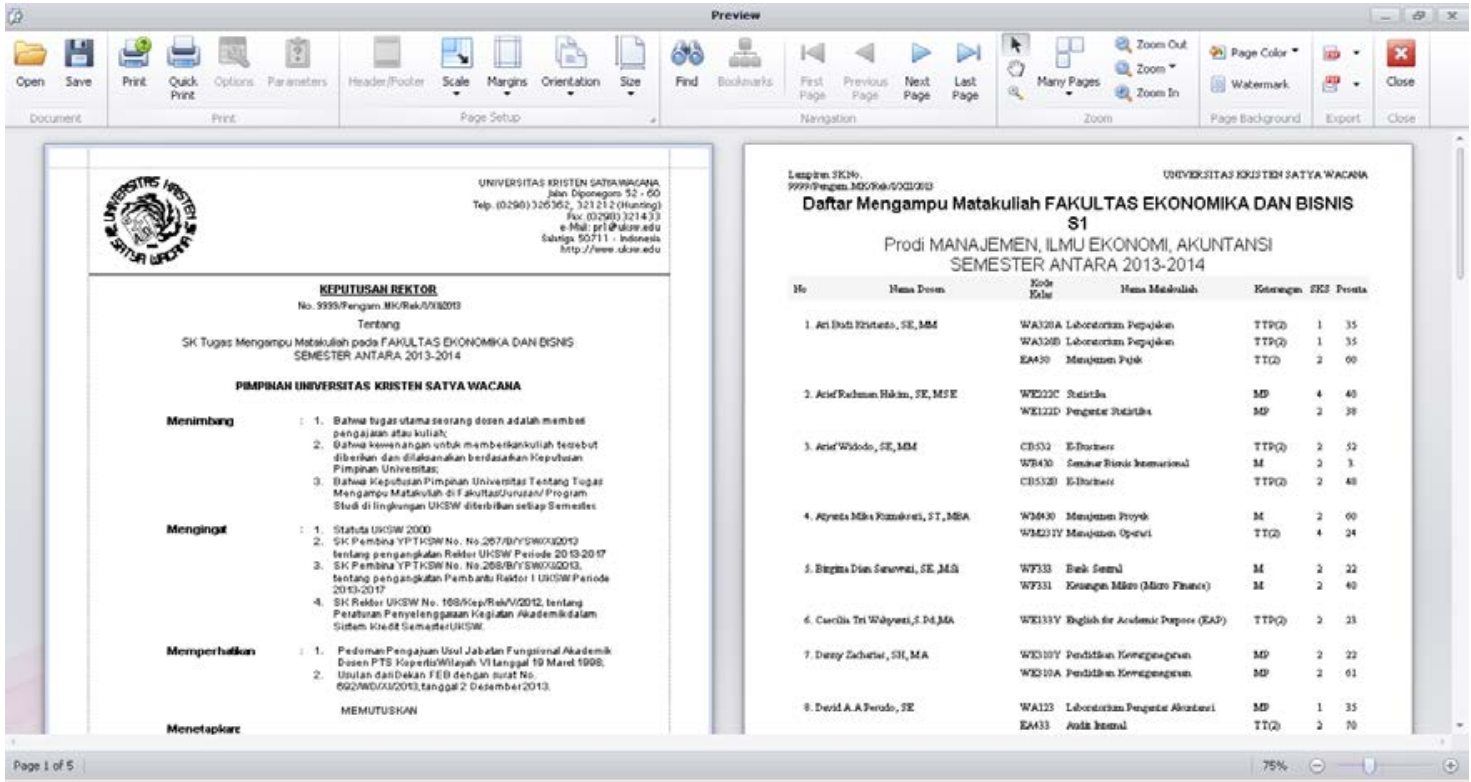

Gambar 10

Tampilan Draf Surat Keputusan Mengajar berserta Lampiran 


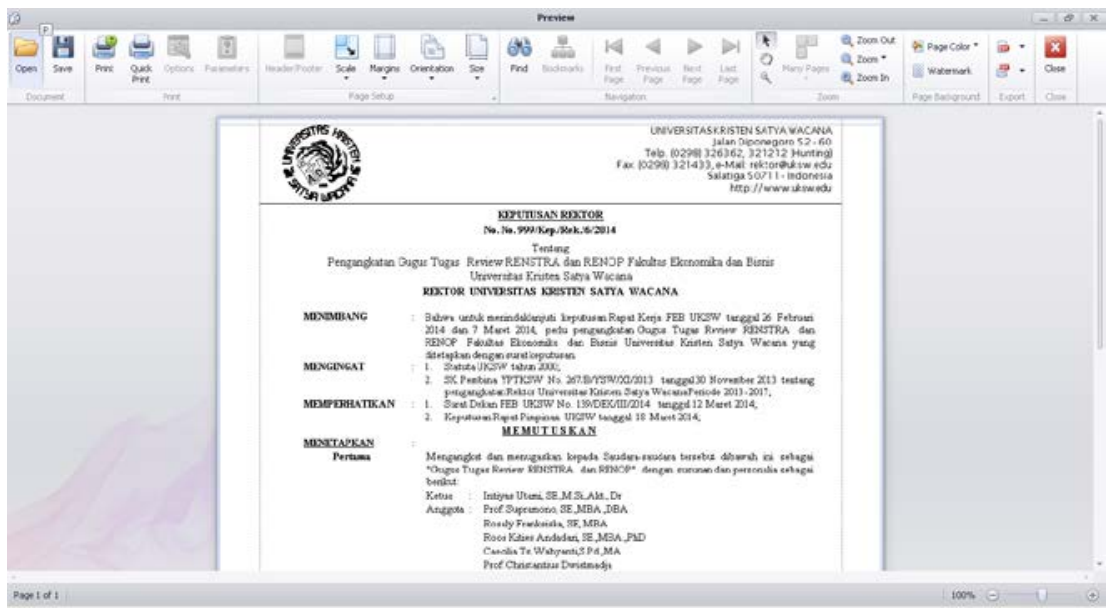

Gambar 11

Surat Keputusan (SK) Satuan Gugus Tugas

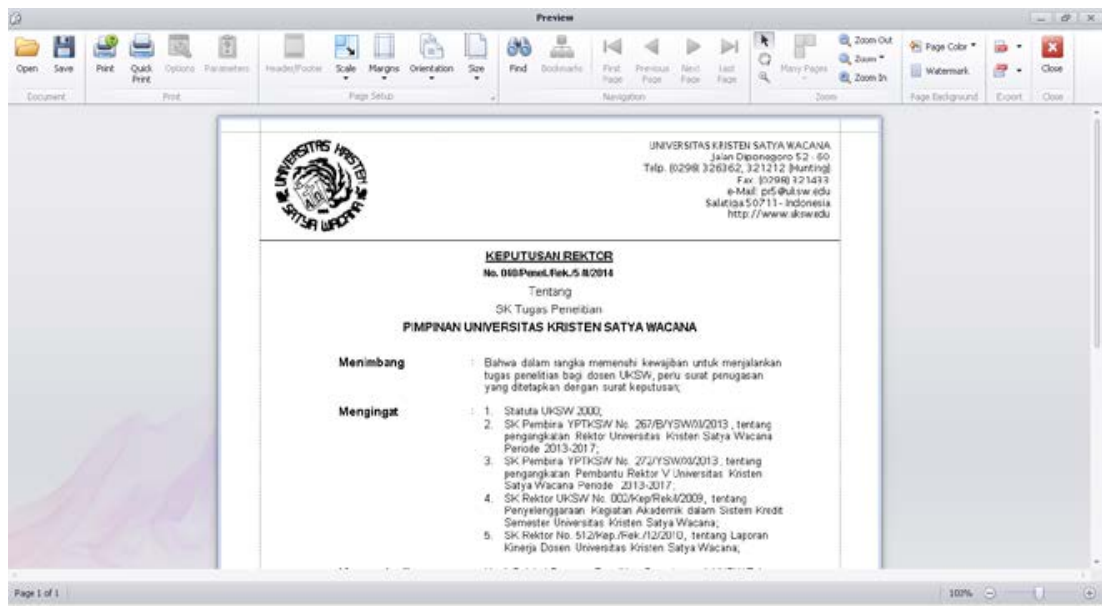

Gambar 12

Surat Keputusan (SK) Tugas Penelitian

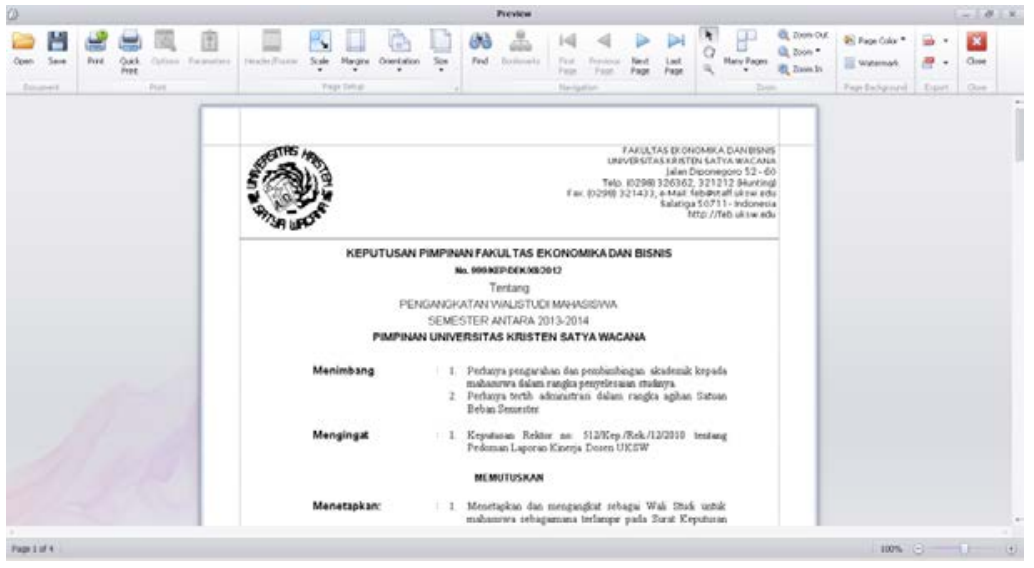

Gambar 13

Surat Keputusan (SK) Pengangkatan Wali Studi Mahasiswa 


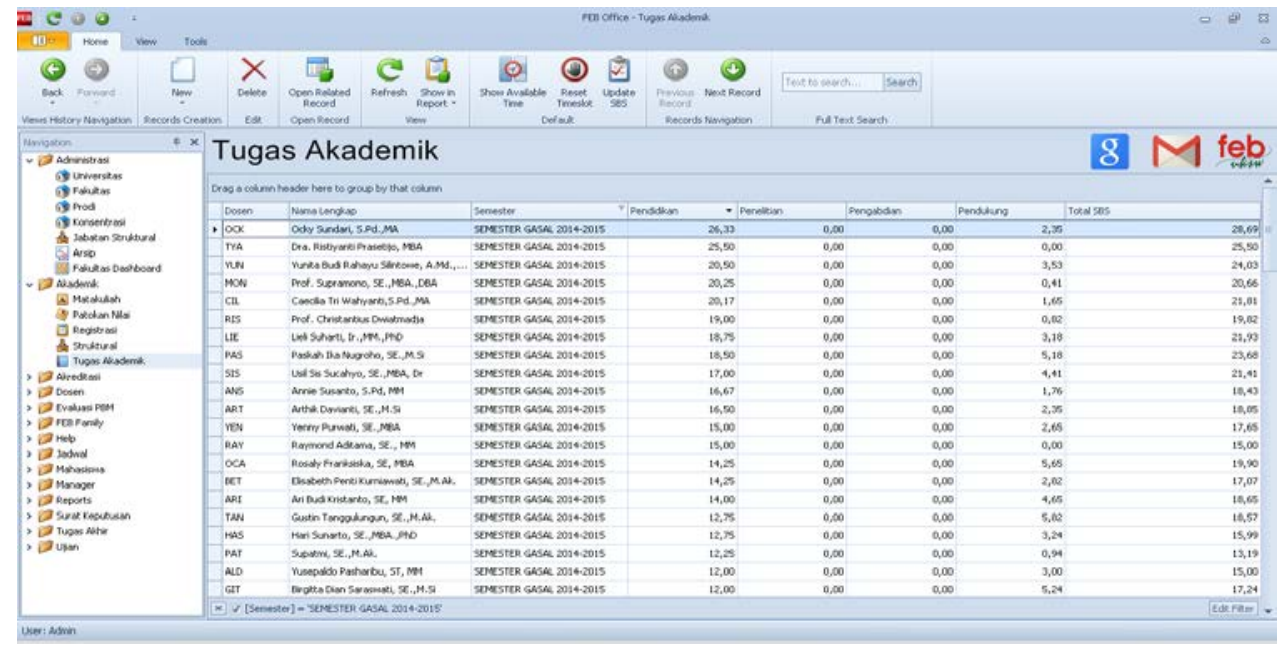

Gambar 14

Dashboard Dosen untuk Tugas Akademik

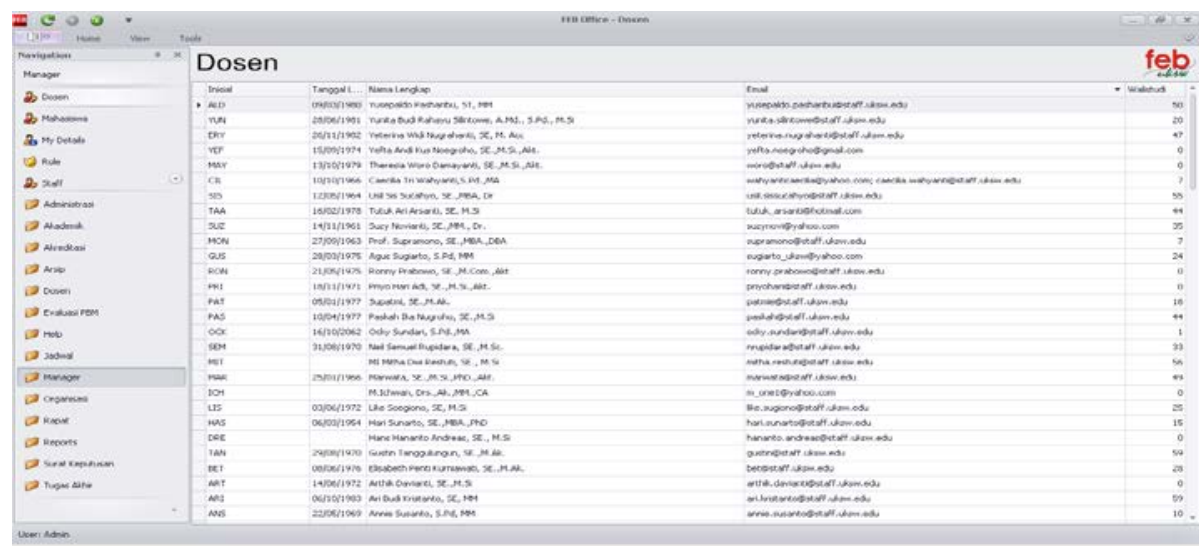

Gambar 15

Dashboard Dosen untuk Jumlah Anak Wali

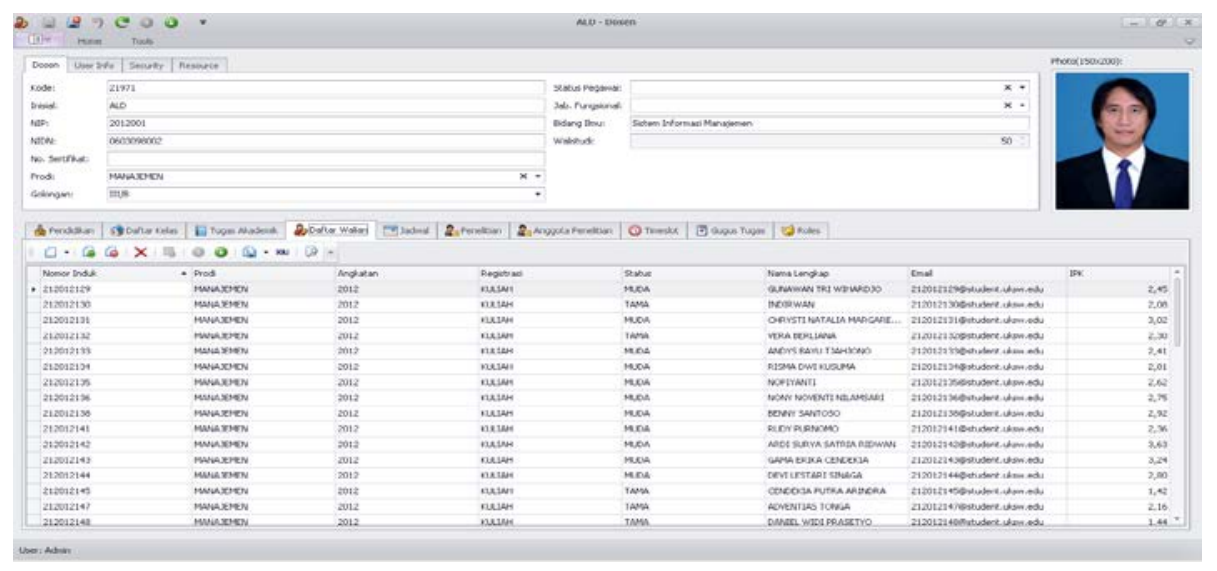

Gambar 16

Dashboard Dosen untuk Data Walian 


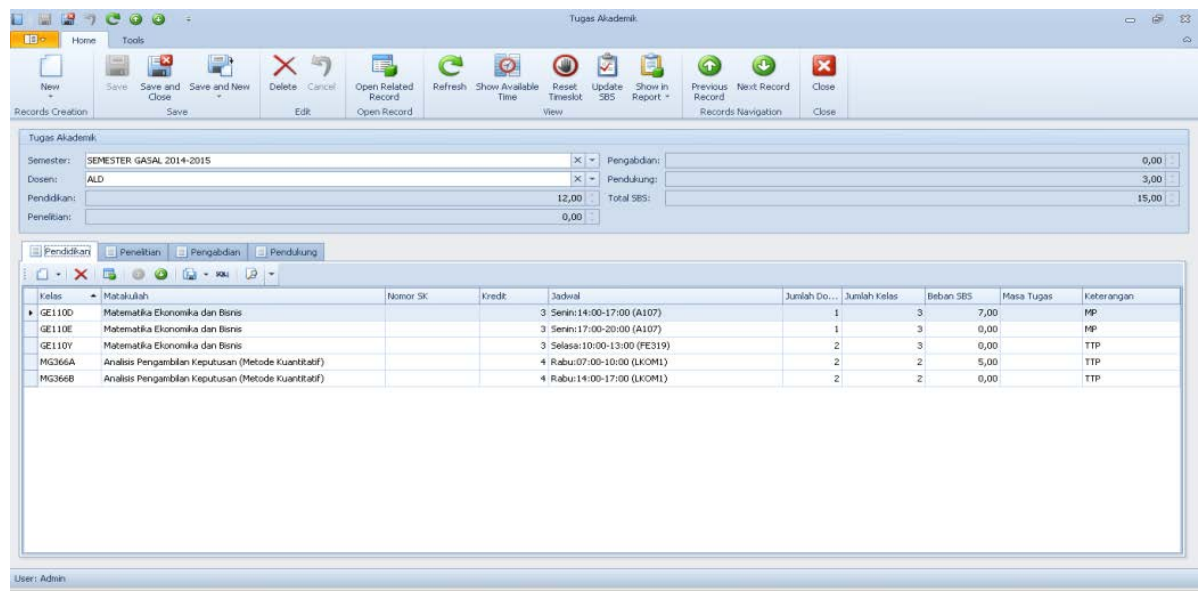

Gambar 17

Dashboard Dosen untuk Mata Kuliah yang Diampu

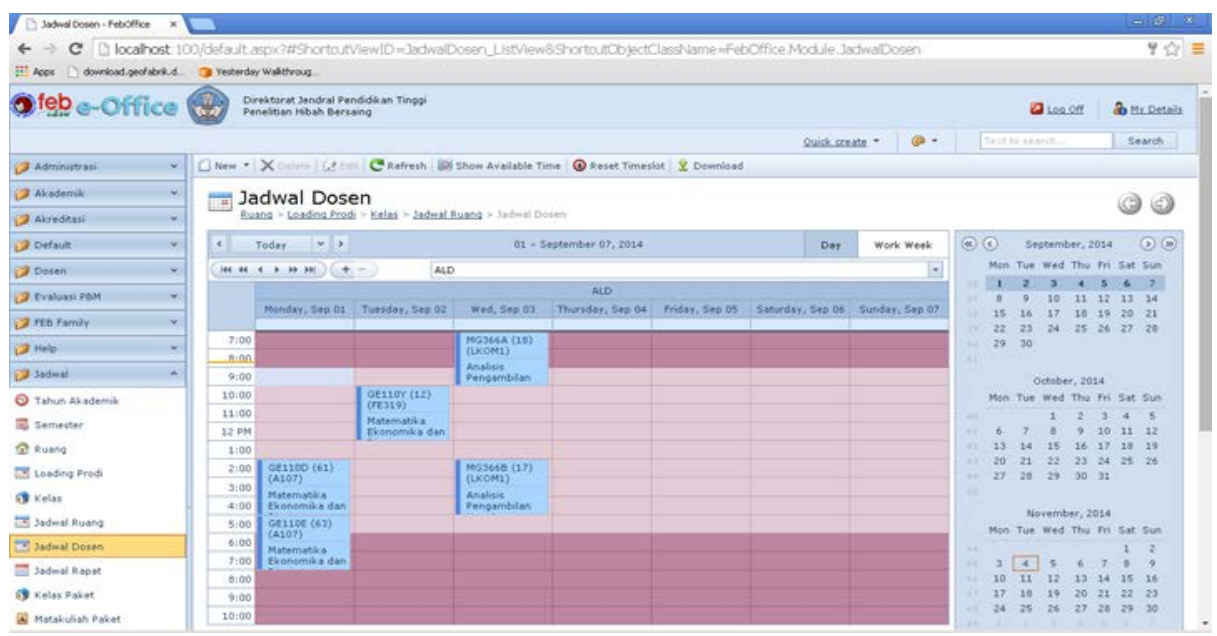

Gambar 18

Dashboard Dosen untuk Jadwal Mata Kuliah yang Diampu

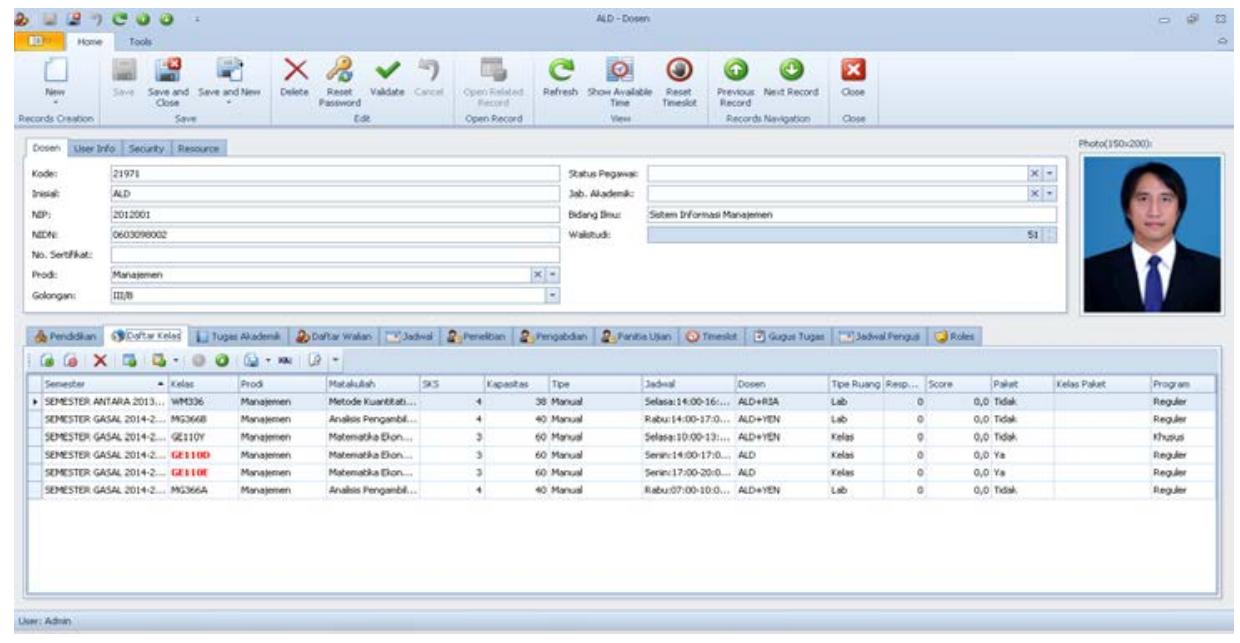

Gambar 19

Dashboard Dosen untuk Daftar Kelas dari Mata Kuliah yang Diampu 


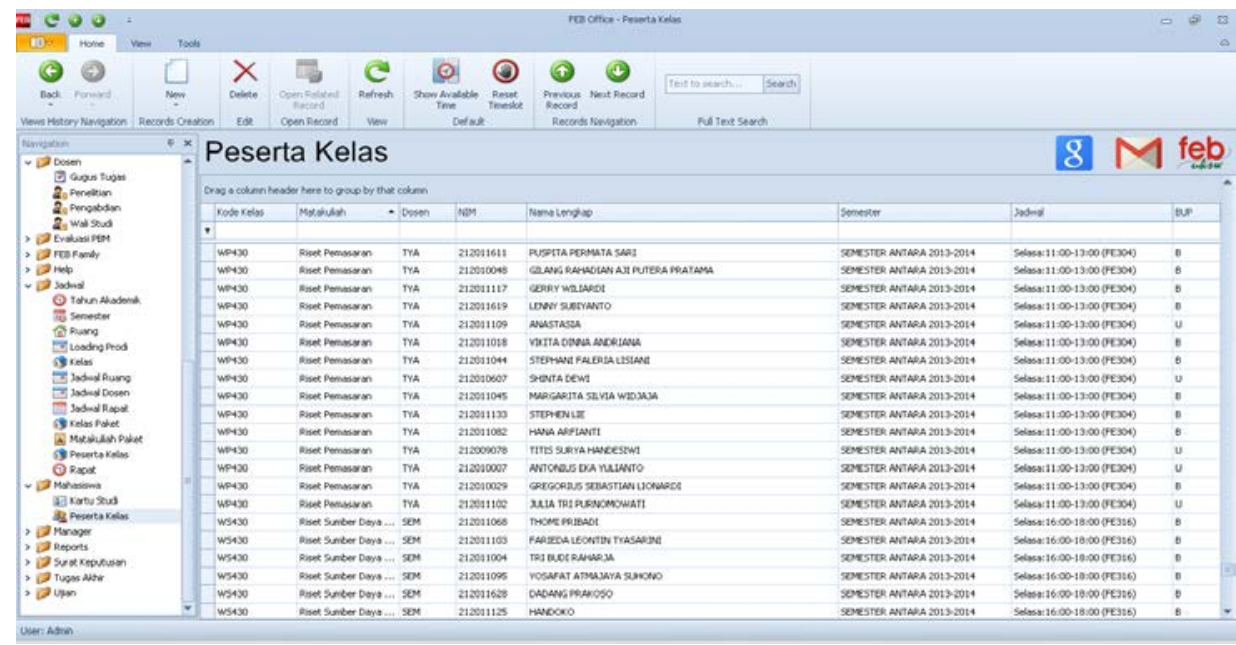

Gambar 20

Dashboard Dosen untuk Peserta Kelas dari Mata Kuliah yang Diampu

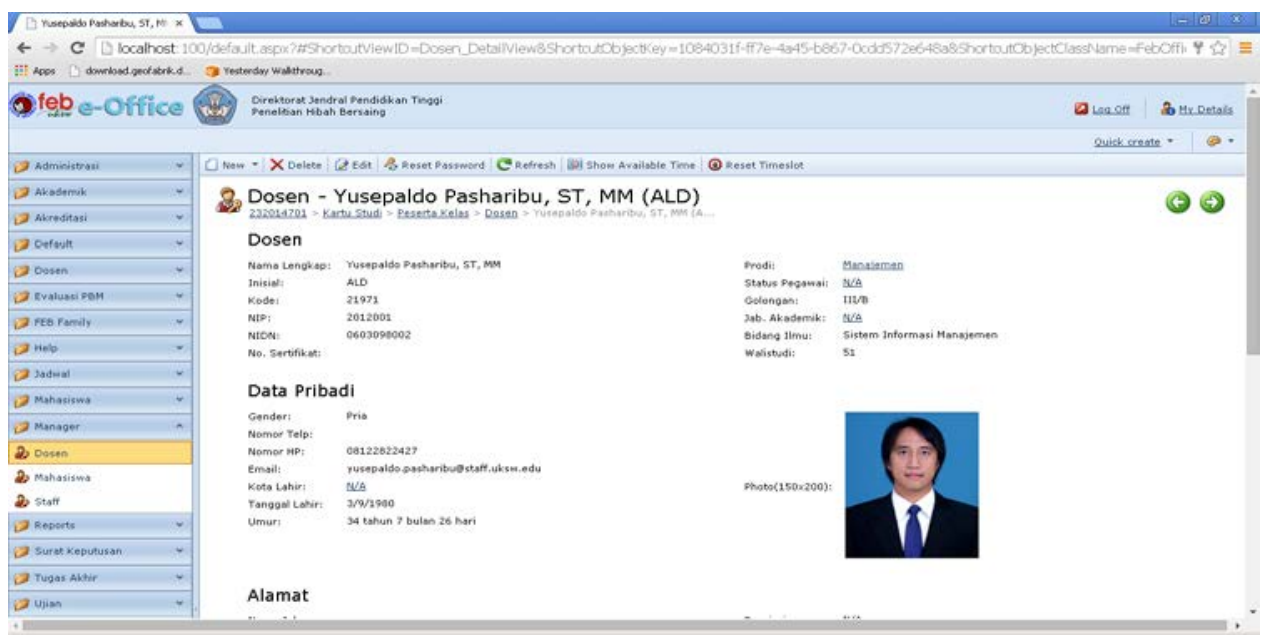

Gambar 21

Dashboard Data Dosen

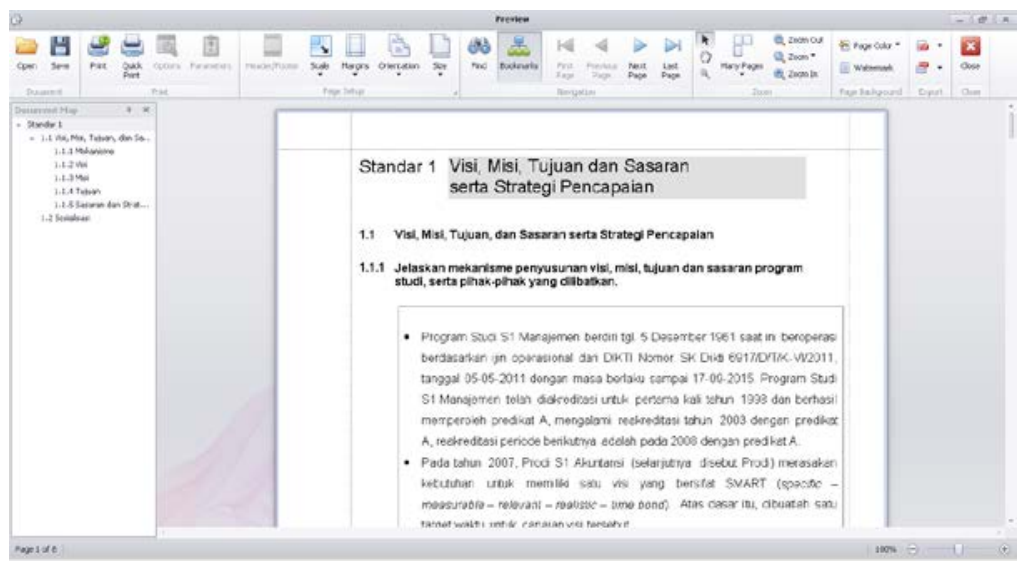

Gambar 22

Tampilan Dokumen Borang Akreditasi 
